\title{
The Medical Library as a Component of a Medical School Outreach Experience
}

The version of record of this manuscript has been published and is available in Medical Reference Services Quarterly Volume 39, 2020 DOI:

10.1080/02763869.2019.1693225

\author{
Jana Schellinger \\ Kathy Cable \\ Milton Bond
}

Kendall M. Campbell 


\begin{abstract}
The US is facing a shortage of physicians for minorities and patients in disadvantaged areas. Many medical schools have pipeline programs to promote the interest of minority students in medicine. The Brody School of Medicine at East Carolina University established the Brody RISE program. Recruitment efforts targeted schools within Pitt County, NC. Students participate in interactive STEM activities and campus tours. Laupus Health Sciences Librarians developed interactive activities that engage critical thinking and teach anatomy and medical history. The organizers of the Brody RISE program continually evaluate and expand the program. Laupus Library continues to partner in these activities.
\end{abstract}

KEYWORDS: Cultural Diversity; Schools, Medical; Education, Medical; Libraries, Medical; Library Services

\title{
AUTHORS
}

Jana Schellinger, MLIS, AHIP (schellingerj18@ecu.edu) is a Liaison Librarian, Laupus Library, East Carolina University, 600 Moye Blvd, Mail Stop 612, Greenville, NC 27834, USA

Kathy Cable, MLS (cablek@ecu.edu) is a Liaison Librarian, Laupus Library, East Carolina University, 600 Moye Blvd, Mail Stop 612, Greenville, NC 27834, USA

Milton Bond, MSA (bondm18@ecu.edu) is the Director of the Brody RISE Program, Brody

School of Medicine, East Carolina University [600 Moye Blvd., Greenville, NC 27834].

Kendall M. Campbell, MD, FAAFP (campbellke16@ecu.edu) is the Senior Associate Dean for Academic Affairs and the Director of The Research Group for Underrepresented Minorities in Academic Medicine, Brody School of Medicine, [600 Moye Blvd., Greenville, NC 27834]

\section{ORCID ID}

Jana Schellinger: 0000-0001-5571-4754

Milton Bond: 0000-0001-8987-8730

Kendall Campbell: 0000-0001-7484-6138 


\section{INTRODUCTION}

The United States is facing a shortage of physicians. With 10,000 individuals turning 65 years old each day, the demand for health services will increase over the next few decades. ${ }^{1}$ Much of the current physician shortage is, in fact, a shortage of primary care physicians available to serve underrepresented minorities and patients in disadvantaged or rural areas. ${ }^{2}$ Underrepresented minority (URM) medical students and those from rural areas are more likely to serve URM and rural patients upon graduation. ${ }^{3-7}$ Unfortunately, URM students and those from disadvantaged or rural areas make up a very small percentage of medical school applicants, students, and, subsequently, physicians. ${ }^{8,9}$

Libraries at colleges, universities, and medical schools are well-positioned to assist these students. Libraries provide free access to textbooks, technology, and research assistance to students across the health sciences, including medical students, dental students, allied health students as well as nursing students. The librarians are a knowledge resource to promote learner success throughout medical school and beyond. Librarian involvement in research and patient care saves time, improves clinical decision-making, reduces patient length of stay, and improves research output. ${ }^{10-14}$

Medical schools are also increasing efforts to recruit and train underrepresented and disadvantaged students. Efforts include the development of pipeline and outreach programs to help develop and maintain the interest of students from middle school through high school in pursuing careers in the medical field. These outreach programs endeavor to provide students with a clear idea of what is involved in a medical education. The goal is to expose them to different areas and experiences within the medical college and strengthen their academic skills to 
prepare them for what lies ahead. Brody School of Medicine (BSOM) at East Carolina University (ECU) is among the schools that maintains a pipeline program called Brody RISE.

The Brody RISE Pre-College Program, founded in the Spring of 2018, provides academic enrichment and healthcare exposure to learners from diverse backgrounds. It is an outreach of the Office of Diversity Affairs of the BSOM. While it may appear that RISE is an acronym, it really describes a pathway that applies the concept of slope and the linear equation $(y=m x+b)$ as the foundation on which RISE was created. The mission of the Brody RISE program is consistent with that of the BSOM and focuses on providing access to a medical education to minority and disadvantaged students (Table 1).

\begin{tabular}{|l|l|}
\hline \multicolumn{1}{|c|}{ BSOM Mission Statement } & \multicolumn{1}{c|}{ Brody RISE Mission Statement } \\
\hline "[T]o increase the supply of primary care & "[T]o increase the supply of primary care \\
physicians serving the state, to improve the & physicians serving the state, improve the \\
health status of eastern North Carolina's & health status of citizens in eastern North \\
citizens, and to enhance access of minority & Carolina and enhance the access of \\
and disadvantaged students to a medical & disadvantaged and minority students to a \\
education"10 & medical education"11 \\
\hline
\end{tabular}

THE MISSION STATEMENTS OF THE BSOM ${ }^{15}$ AND THE BRODY RISE PROGRAM ${ }^{16}$

The Brody RISE program "meets learners where they are, across the spectrum of academic accomplishment. Learners will RISE to a career in healthcare and research while increasing leadership skills and professionalism." ${ }^{\prime 6}$ Students learn about the BSOM, the Honors College, and simulation labs, and they have an opportunity to interact with faculty and students in the health professions. Students participate in STEM activities with a focus on healthcare. They visit the Interprofessional Clinical Simulation Program at BSOM and work with manikins in real life 
clinical scenarios. They also tour the DaVinci robotic lab at the East Carolina Heart Institute where they learn about robotic surgery and use a training robot to manipulate objects.

As many of these students are from low income households, the program also provides a realistic idea of the unique challenges students from rural, disadvantaged, and underserved populations may experience. Students learn about programs that are available to assist them in pursuing a medical education, such as scholarship opportunities and financial aid.

In conjunction with the Brody RISE program, school groups from middle school through college can tour the health sciences campus and participate in interactive activities. In the 2018-2019 school year, the RISE program hosted students from the following schools for tours and activities:

- J.H. Rose High School - Taking Steps Beyond Rose Program

- $\quad$ North Carolina State University - North Carolina Mathematics and Science Education Network

- $\quad$ North Carolina Central University - STEM Promise Living Learning Community

- $\quad$ Pactolus K-8 School

- University of North Carolina at Pembroke - Project Access

- University of North Carolina at Pembroke - Safeguarding Our Natural and Tribal Heritage Youth Program (SONTH)

In addition to school tours, Brody RISE leaders also recruited middle school students who participated in two components: 
1. Saturday Academy - students attended sessions from 9am-1pm for 16 weeks during the school year.

2. Summer Camp - students attended a two-week summer day-camp program

Selection of pre-college participants for the Brody RISE program involved a review of the demographic data for the state of North Carolina and BSOM (Table 2).

\begin{tabular}{|l|c|c|c|c|c|}
\hline & $\begin{array}{c}\text { BSOM } \\
2016\end{array}$ & $\begin{array}{c}\text { BSOM } \\
2017\end{array}$ & $\begin{array}{c}\text { BSOM } \\
2018\end{array}$ & $\begin{array}{c}\text { BSOM } \\
2019\end{array}$ & NC \\
\hline Population & 82 & 86 & 86 & 86 & $9,535,483$ \\
\hline Black/African American & $11(13 \%)$ & $7(8 \%)$ & $18(21 \%)$ & $18(21 \%)$ & $22.2 \%$ \\
\hline Asian & $11(13 \%)$ & $13(15 \%)$ & $13(15 \%)$ & $13(15 \%)$ & $3.2 \%$ \\
\hline Latino/Hispanic & $3(3.5 \%)$ & $3(3.5 \%)$ & $10(11.5 \%)$ & $7(8 \%)$ & $9.6 \%$ \\
\hline Native American/Alaska Native & 0 & $1(1 \%)$ & 0 & $1(1 \%)$ & $1.6 \%$ \\
\hline White & $50(61 \%)$ & $55(64 \%)$ & $42(49 \%)$ & $42(49 \%)$ & $70.6 \%$ \\
\hline Other/None Selected & $5(6 \%)$ & $3(3.5 \%)$ & $3(3.5 \%)$ & $5(6 \%)$ & $2.3 \%$ \\
\hline
\end{tabular}

DEMOGRAPHIC DATA FOR STATE OF NC ${ }^{17}$ AND BSOM ENTERING CLASSES ${ }^{15}$

Middle and high schools with populations of underrepresented minority students at state census data levels or above were initially sought for participation. Program participation requirements include a 3.0 Grade Point Average (GPA), a completed online application packet including three letters of recommendation, and an essay indicating reasons for wanting to participate in the program. The program began serving learners in Pitt County, North Carolina and successfully recruited middle school students from the following schools: Wellcome Middle School, Pactolus K-8 School, Ayden Middle School, and Hope Middle School. All of the partner schools are considered Title 1 schools, which means that at least $75 \%$ of the students from the district are considered economically disadvantaged and qualify for the free lunch program. ${ }^{18}$ 


\section{PROGRAM DESCRIPTION:}

The campus library, the Laupus Health Sciences Library on the health sciences campus of ECU, is a rich source of support for the school. Students at the BSOM are introduced to their liaison librarians at orientation and are encouraged to utilize the library and its services throughout their matriculation. The library also serves the surrounding community through outreach efforts, the faculty and staff of the BSOM, and the Vidant Health System, which is the health system affiliated with the BSOM. Because the library is such an integral part of a medical education at ECU, a natural fit for the programming of the Brody RISE program was partnering with the campus library to provide resources and instructions for RISE learners. The Brody RISE program introduced students to the library, the two liaison librarians to the BSOM, and library services during their program experience.

Librarians were eager to participate in this program, as it correlates with the mission of the library, to "provide leadership in access to information essential to quality health care delivery, education, and research at East Carolina University and across eastern North Carolina". ${ }^{19}$ This program also correlates with the mission of the Medical Library Association (MLA), the librarians' professional organization, by building partnerships and supporting diversity, equity, and inclusion. ${ }^{20}$ The librarians at Laupus Library have a mission to make patrons comfortable with the use of the library and its services. Although the library participates in other outreach efforts, they are geared toward medical professionals in surrounding communities instead of potential students. Librarians were eager to create activities for this worthwhile program.

RISE organizers requested that library activities be interactive, encourage critical thinking, and relate to the work of the library. The librarians' goal was to tie learning back to the Association 
of College \& Research Libraries (ACRL) Framework for Information Literacy for Higher Education frames $^{21}$, which guide library instruction in these and other regular instruction sessions. Librarians searched the literature for similar programs at other libraries but were unable to find examples. The librarians then created individual and team activities for the students based on medical history, anatomy, and research publication. Activities were geared toward students of multiple ages and abilities and could be selected based on the student group and time allotment. (Table 3).

\begin{tabular}{|c|c|c|c|}
\hline Activity & Description & $\begin{array}{l}\text { How Was Learning } \\
\text { Assessed }\end{array}$ & ACRL Frame ${ }^{21}$ \\
\hline $\begin{array}{l}\text { Critical } \\
\text { Appraisal } \\
\text { of } \\
\text { Predatory } \\
\text { Journals }\end{array}$ & $\begin{array}{l}\text { Students learned about } \\
\text { predatory journals and } \\
\text { discussed how to } \\
\text { critically appraise what } \\
\text { they read }\end{array}$ & $\begin{array}{l}\text { Post-activity evaluation } \\
100 \% \text { of students } \\
\text { identified the main } \\
\text { takeaway idea of the } \\
\text { importance of critically } \\
\text { appraising what they } \\
\text { read }\end{array}$ & $\begin{array}{l}\text { Authority is Constructed } \\
\text { and Contextual } \\
\text { Information has Value } \\
\text { Research as Inquiry }\end{array}$ \\
\hline $\begin{array}{l}\text { Anatomical } \\
\text { Cutouts }\end{array}$ & $\begin{array}{l}\text { Students chose cutouts of } \\
\text { appropriate organs based } \\
\text { on system and placed } \\
\text { them in the correct } \\
\text { location on a paper } \\
\text { cutout of a body }\end{array}$ & $\begin{array}{l}\text { Evaluation of } \\
\text { performance of the task } \\
\text { Students used teamwork } \\
\text { to correctly identify the } \\
\text { organs involved in body } \\
\text { systems and place them } \\
\text { in the correct location }\end{array}$ & $\begin{array}{l}\text { Authority is Constructed } \\
\text { and Contextual }\end{array}$ \\
\hline $\begin{array}{l}\text { Timeline } \\
\text { Game }\end{array}$ & $\begin{array}{l}\text { Students placed events } \\
\text { and medical discoveries } \\
\text { in order on a timeline }\end{array}$ & $\begin{array}{l}\text { Evaluation of } \\
\text { performance of the task } \\
\text { Students used teamwork, } \\
\text { critical thinking skills } \\
\text { and knowledge of history } \\
\text { to correctly identify } \\
\text { dates of medical } \\
\text { innovations }\end{array}$ & $\begin{array}{l}\text { Authority is Constructed } \\
\text { and Contextual } \\
\text { Information Creation as } \\
\text { a Process } \\
\text { Research as Inquiry }\end{array}$ \\
\hline
\end{tabular}




\begin{tabular}{|l|l|l|l|}
\hline $\begin{array}{l}\text { Folk } \\
\text { Remedies } \\
\text { Matching } \\
\text { Game }\end{array}$ & $\begin{array}{l}\text { Students matched folk } \\
\text { remedies to the illnesses } \\
\text { or ailments they were } \\
\text { thought to cure }\end{array}$ & $\begin{array}{l}\text { Evaluation of } \\
\text { performance of the task }\end{array}$ & $\begin{array}{l}\text { Authority is Constructed } \\
\text { and Contextual }\end{array}$ \\
& $\begin{array}{l}\text { Students individually } \\
\text { used logic and } \\
\text { knowledge of history to } \\
\text { match remedies to } \\
\text { ailments. Much lively } \\
\text { discussion occurred. }\end{array}$ & $\begin{array}{l}\text { a Process } \\
\text { Information Has Value }\end{array}$ \\
& & & \\
\hline
\end{tabular}

ACTIVITIES USED WITH BRODY RISE STUDENTS

In the 2018-2019 school year and the following summer, the library provided tours and activities to students from North Carolina Central University, J.H. Rose High School, and middle school students from Pactolus K-8 School. The library was also involved in both the Saturday Academy during the 2018-2019 school year and Summer Camp for the summer of 2019.

\section{RESULTS}

To date, five groups of students, ranging from middle school through early college, have participated in library activities (Table 4). Thirteen students from J.H. Rose High School (4/1/19), 19 middle school students from Pactoulous K-8 school (4/11/19), and 12 students from North Carolina Central University (4/9/19) came to the library for tours and activities (Total 44). The library hosted six students for the Saturday Academy (2/16/19). Those students returned with 11 additional students for summer camp (6/21/19). All of the students who participated in the Saturday Academy were from Wellcome and Pactolus schools. Fifteen of the 17 students who participated in summer camp were from the same schools, with one additional student coming from Ayden and another one coming from Hope. 


\begin{tabular}{|c|c|c|c|c|c|c|c|}
\hline & \multirow{2}{*}{ Ayden } & \multirow{2}{*}{ Hope } & \multirow{2}{*}{$\begin{array}{l}\text { J.H. } \\
\text { Rose }\end{array}$} & \multirow{2}{*}{ Pactolus } & \multirow{2}{*}{ Wellcome } & \multicolumn{2}{|c|}{$\begin{array}{l}\text { Brody RISE } \\
\text { Participants }\end{array}$} \\
\hline & & & & & & $\begin{array}{l}\text { Saturday } \\
\text { Academy }\end{array}$ & $\begin{array}{c}\text { Summer } \\
\text { Camp }\end{array}$ \\
\hline $\begin{array}{c}\text { Grades at the } \\
\text { School }\end{array}$ & $6-8$ & $6-8$ & $9-12$ & Pk-8 & $6-8$ & $6-8$ & $6-8$ \\
\hline $\begin{array}{c}\text { Total } \\
\text { Students }\end{array}$ & 329 & 762 & 1516 & 550 & 394 & 6 & 17 \\
\hline $\begin{array}{c}\text { Black/African } \\
\text { American }\end{array}$ & $\begin{array}{c}114 \\
(34.5 \%)\end{array}$ & $\begin{array}{c}181 \\
(23.5 \%)\end{array}$ & $\begin{array}{c}793 \\
(52 \%)\end{array}$ & $\begin{array}{c}216 \\
(39 \%)\end{array}$ & $\begin{array}{c}207 \\
(52.5 \%)\end{array}$ & $\begin{array}{c}1 \\
(16.5 \%)\end{array}$ & $\begin{array}{c}7 \\
(41 \%)\end{array}$ \\
\hline Asian & $\begin{array}{c}2 \\
(.6 \%) \\
\end{array}$ & $\begin{array}{c}36 \\
(.5 \%) \\
\end{array}$ & $\begin{array}{c}43 \\
(3 \%) \\
\end{array}$ & $\begin{array}{c}3 \\
(.5 \%) \\
\end{array}$ & 0 & $\mathbf{0}$ & $\mathbf{0}$ \\
\hline $\begin{array}{l}\text { Latino/ } \\
\text { Hispanic }\end{array}$ & $\begin{array}{c}45 \\
(13.5 \%)\end{array}$ & $\begin{array}{c}49 \\
(6 \%)\end{array}$ & $\begin{array}{c}89 \\
(6 \%)\end{array}$ & $\begin{array}{c}210 \\
(38 \%)\end{array}$ & $\begin{array}{c}140 \\
(35.5 \%)\end{array}$ & $\begin{array}{c}2 \\
(33 \%)\end{array}$ & $\begin{array}{c}7 \\
(41 \%)\end{array}$ \\
\hline $\begin{array}{l}\text { Native } \\
\text { American/ } \\
\text { Alaska } \\
\text { Native }\end{array}$ & $\begin{array}{c}1 \\
(.3 \%)\end{array}$ & $\begin{array}{c}2 \\
(.3 \%)\end{array}$ & $\begin{array}{c}2 \\
(.1 \%)\end{array}$ & $\begin{array}{c}2 \\
(.3 \%)\end{array}$ & 0 & $\mathbf{0}$ & $\mathbf{0}$ \\
\hline White & $\begin{array}{c}157 \\
(47 \%)\end{array}$ & $\begin{array}{c}466 \\
(61 \%)\end{array}$ & $\begin{array}{c}548 \\
(36 \%)\end{array}$ & $\begin{array}{c}105 \\
(19 \%)\end{array}$ & $\begin{array}{c}38 \\
(9.6 \%)\end{array}$ & $\mathbf{0}$ & $\mathbf{0}$ \\
\hline $\begin{array}{c}\text { Two or More } \\
\text { Races } \\
\end{array}$ & $\begin{array}{c}10 \\
(3 \%) \\
\end{array}$ & $\begin{array}{c}27 \\
(3.5 \%) \\
\end{array}$ & $\begin{array}{c}41 \\
2.5 \%) \\
\end{array}$ & $\begin{array}{c}14 \\
(2.5 \%) \\
\end{array}$ & $\begin{array}{c}9 \\
(2 \%) \\
\end{array}$ & $\begin{array}{c}1 \\
(16.5 \%) \\
\end{array}$ & $\begin{array}{c}1 \\
(6 \%) \\
\end{array}$ \\
\hline $\begin{array}{c}\text { Students did } \\
\text { not self- } \\
\text { identify } \\
\end{array}$ & 0 & 0 & 0 & 0 & 0 & $\begin{array}{c}2 \\
(16.5 \%)\end{array}$ & $\begin{array}{c}2 \\
(12 \%)\end{array}$ \\
\hline
\end{tabular}

DEMOGRAPHIC DATA ABOUT PIPELINE PARTICIPANT SCHOOLS ${ }^{22}$ AND

\title{
PIPELINE STUDENTS*
}

\begin{abstract}
* No demographic data is available for North Carolina Central University (NCCU); however, NCCU is a historically black university
\end{abstract}

The response to the library activities has been overwhelmingly positive. Students have been pleased with the experience and activities. A post-activity evaluation conducted after the Critical Appraisal of Predatory Journals showed that $100 \%$ of the students identified the main takeaway idea from the lesson (from post-activity evaluation, June 21, 2019). After a Saturday morning at 
the library, one student stated she wished school was more like this (from post-activity evaluation, April 9, 2019).

Some suggestions for librarians who are thinking about implementing similar programs include:

- $\quad$ Develop and maintain a relationship of cooperation with library champions in whatever department you serve. As opportunities to collaborate arise, hopefully they will reach out to the library.

- $\quad$ Over-plan - It is difficult to know how long students will require for an activity. It is best to have more activities than you think you need for the time allotted. You can always use any activities that you don't get to with the next group or for future interactions with the same students.

- $\quad$ Plan a variety of activities - Some students will be very engaged with one type of activity while other students will be engaged with different activities. If you have a variety of activities to choose from, you will be better equipped to engage the largest number of students.

- $\quad$ Be flexible - You may not have a lot of notice prior to these groups. Groups will be different sizes and will have different levels of engagement. If you are flexible, you can plan for your groups and change from one activity to another easily.

- $\quad$ Create a toolbox of activities to draw from - This will allow you to arrange a session quickly and with minimal difficulty.

- $\quad$ Ask lots of questions - Engage the students in discussion. When examining a special technology while touring the library, ask "Why do you think this technology is helpful to medical students?" or "What are some ways you would use this technology if 
you were studying to be a doctor?" After an interactive game, ask the students, "Why do you think it's important for medical students to be aware of when medical discoveries were made?" or "Why do you think people used this folk remedy?" Discuss their responses.

- $\quad$ Be creative - All activities, except for the sachet bags craft, were produced with materials on-hand at the library and were implemented by a single librarian. You do not need to have a lot of funding or a large staff to implement a project like this.

\section{FUTURE DIRECTIONS:}

Plans are to expand the Brody RISE program to include additional schools within and around Pitt County. The vision is to include learners from middle school to medical school and beyond, creating a pathway that increases numbers of minority and disadvantaged students in healthcare and research. Increasing parent involvement in the program is planned as well as the addition of an afterschool program. Plans are also to convert the summer camp into a residential summer camp that would allow a more complete immersion into the medical school experience for RISE participants. The Laupus Health Sciences Librarians will continue to be an integral part of these future endeavors and will continue to develop engaging and interactive activities for the Brody RISE students. Librarians are already developing activities including utilization of the library's new Virtual Reality lab to examine anatomy resources, exploring information literacy concepts, and exploring information searching skills.

\section{CONCLUSION:}

The library component of this outreach program has been an enjoyable experience for the librarians and has achieved its aims. Interactive activities engaged students and fostered critical 
thinking. Librarians were able to tie learning back to the ACRL framework. The librarians will continue to work with the Brody RISE program, developing new activities and hosting students for interactive and engaging activities. Longitudinally, we will know if the Brody RISE program is a success based on the number of these students who pursue medical careers and subsequently serve URM communities.

Declaration of Interest Statement: The authors declare no conflicts of interest 


\section{REFERENCES}

1. Kirch, Darrell G. and Kate Petelle. "Addressing the Physician Shortage: The Peril of Ignoring Demography." Jama 317, no. 19 (May 16, 2017): 1947-1948.

doi:10.1001/jama.2017.2714. http://dx.doi.org/10.1001/jama.2017.2714.

2. Campbell, K. M., N. C. Brownstein, H. Livingston, and J. E. Rodriguez. "Improving Underrepresented Minority in Medicine Representation in Medical School." Southern Medical Journal 111, no. 4 (April 01, 2018): 203-208.

doi:10.14423/SMJ.0000000000000792 [doi].

3. Gross, D. A., L. C. Mattox, and N. Winkleman. "Priming the Physician Pipeline: A Regional AHEC's use of in-State Medical School Data to Guide its Health Careers Programming." Journal of Health Care for the Poor and Underserved 27, no. 4A (2016): 8-18. doi:S1548686916400458 [pii].

4. Quinn, K. J., K. Y. Kane, J. J. Stevermer, W. D. Webb, J. L. Porter, H. A. Williamson Jr, and M. C. Hosokawa. "Influencing Residency Choice and Practice Location through a Longitudinal Rural Pipeline Program." Academic Medicine : Journal of the Association of American Medical Colleges 86, no. 11 (Nov, 2011): 1397-1406. doi:10.1097/ACM.0b013e318230653f [doi].

5. Wenghofer, E. F., J. C. Hogenbirk, and P. E. Timony. "Impact of the Rural Pipeline in Medical Education: Practice Locations of Recently Graduated Family Physicians in Ontario." Human Resources for Health 15, no. 1 (Feb 20, 2017): 1-6. doi:10.1186/s12960-017-0191-6 [doi].

6. Kwan, M. M. S., S. Kondalsamy-Chennakesavan, G. Ranmuthugala, M. R. Toombs, and G. C. Nicholson. "The Rural Pipeline to Longer-Term Rural Practice: General Practitioners and Specialists." PloS One 12, no. 7 (Jul 7, 2017): e0180394. doi:10.1371/journal.pone.0180394 [doi].

7. Rourke, J., S. Asghari, O. Hurley, M. Ravalia, M. Jong, W. Parsons, N. Duggan, et al. "From Pipelines to Pathways: The Memorial Experience in Educating Doctors for Rural Generalist Practice." Rural and Remote Health 18, no. 1 (Mar, 2018): 4427. doi:10.22605/RRH4427 [doi].

8. Mains, Tyler E., Mark V. Wilcox, and Scott M. Wright. "Medical Education Resources Initiative for Teens Program in Baltimore: A Model Pipeline Program Built on Four Pillars." Education for Health (Abingdon, England) 29, no. 1 (Jan-Apr, 2016): 47-50. doi:10.4103/1357-6283.178935.

9. Nair, Navya, Ariel E. Marciscano, Karina L. Vivar, Sarah Schaeffer, Elizabeth LaMont, and Fritz Francois. "Introduction to the Medical Professions through an Innovative Medical Student-Run Pipeline Program." Journal of the National Medical Association 103, no. 9-10 (Sep-Oct, 2011): 832-838.

10. Weightman, Alison L. and Jane Williamson. "The Value and Impact of Information Provided through Library Services for Patient Care: A Systematic Review." Health 
Information and Libraries Journal 22, no. 1 (Mar, 2005): 4-25. doi:10.1111/j.14711842.2005.00549.x.

11. Brettle, Alison, Michelle Maden-Jenkins, Lucy Anderson, Rosalind McNally, Tracey Pratchett, Jenny Tancock, Debra Thornton, and Anne Webb. "Evaluating Clinical Librarian Services: A Systematic Review." Health Information and Libraries Journal 28, no. 1 (Mar, 2011): 3-22. doi:10.1111/j.1471-1842.2010.00925.x.

12. Cooper, I. Diane and Janet A. Crum. "New Activities and Changing Roles of Health Sciences Librarians: A Systematic Review, 1990-2012." Journal of the Medical Library Association: JMLA 101, no. 4 (Oct, 2013): 268-277. doi:10.3163/1536-5050.101.4.008.

13. Perrier, Laure, Ann Farrell, A. Patricia Ayala, David Lightfoot, Tim Kenny, Ellen Aaronson, Nancy Allee, et al. "Effects of Librarian-Provided Services in Healthcare Settings: A Systematic Review." Journal of the American Medical Informatics Association: JAMIA 21, no. 6 (Nov-Dec, 2014): 1118-1124. doi:10.1136/amiajnl-2014002825 .

14. Richardson, Joshua E., Daina R. Bouquin, Lyubov L. Tmanova, and Drew Wright. "Information and Informatics Literacies of First-Year Medical Students." Journal of the Medical Library Association: JMLA 103, no. 4 (Oct, 2015): 198-202. doi:10.3163/15365050.103.4.008.

15. East Carolina University - Brody School of Medicine. "Meeting our Mission". Accessed July 22, 2019. https://medicine.ecu.edu/mission/.

16. East Carolina University Office of Diversity Affairs. "Brody Rise". Accessed 5/10/, 2019. https://medicine.ecu.edu/diversityaffairs/brody-rise/.

17. United States Census Bureau. "QuickFacts North Carolina". Accessed July 22/, 2019. https://www.census.gov/quickfacts/NC.

18. Pitt County Schools. "Federal Programs - Title I." . Accessed July 22, 2019. https://www.pitt.k12.nc.us/Page/145.

19. Laupus Health Sciences Library. "About the Library." East Carolina Unviersity, 2019. https://hsl.ecu.edu/about/about-the-library/

20. Medical Library Association. “About MLA.” Medical Library Association, 2019. https://www.mlanet.org/p/cm/ld/fid=21.

21. Association of College \& Research Libraries. "Framework for Information Literacy for Higher Education".

22. National Center for Education Statistics. "Search for Public Schools - Pitt County, NC". Accessed July 22, 2019. https://nces.ed.gov/ccd/schoolsearch/school_list.asp?Search=1\&InstName=\&SchoolID= $\&$ Address $=\&$ City $=\&$ State $=37 \&$ Zip $=\&$ Miles $=\&$ County $=$ Pitt $\&$ PhoneAreaCode $=\&$ Phone $=$ $\&$ DistrictName $=\&$ DistrictID=3700012 $\&$ SchoolType $=1 \&$ SchoolType $=2 \&$ SchoolType $=3$ $\&$ SchoolType=4\&SpecificSchlTypes=all\&IncGrade=-1\&LoGrade=-1\&HiGrade=-1 . 